\title{
Anatomical Characteristics through Computed Tomography Analysis in Patients Undergoing Revision Endoscopic Sinus Surgery
}

\author{
Kyu Eun Lee, Hyun Sang Cho, Su Jin Lim, Jin Wook Kwak, Kyung Soo Kim and Hyun Jik Kim \\ Department of Otolaryngology-Head and Neck Surgery, Chung-Ang University College of Medicine, Seoul, Korea
}

\section{전산화단층촬영의 분석을 통한 비부비동 내시경 재수술에 영향을 미친 해부학적 구조 및 비정상적 소견}

이규은 · 조현상 · 임수진 · 곽진욱 · 김경수 · 김현직

중앙대학교 의과대학 이비인후과학교실

Received July 20, 2013

Revised September 24, 2013

Accepted September 25, 2013

Address for correspondence

Hyun Jik Kim, MD, PhD

Department of Otolaryngology-

Head and Neck Surgery,

Chung-Ang University

College of Medicine,

102 Heukseok-ro, Dongjak-gu,

Seoul 156-755, Korea

Tel $+82-2-6299-1782$

Fax $+82-2-825-1765$

E-mail hyunjk@cau.ac.kr
Background and Objectives The aim of this study was to evaluate the non-dissected anatomic structures and abnormal computed tomographic findings that contribute to the recurrence of chronic rhinosinusitis (CRS) or the trail of revision endoscopic sinus surgery (ESS).

Subjects and Method The medical records of 34 subjects who were diagnosed with recurrent chronic rhinosinusitis, and required to undergo revision endoscopic sinus surgery were collected retrospectively. The subjects' computed tomography results were examined by a radiology specialist.

Results The most common anatomic factors associated with the revision ESS for recurrence of CRS or retained inflammation were residual uncinate process $(47.0 \%)$ and residual anterior ethmoidal cells followed by undissected posterior ethmoidal cells $(38.2 \%)$ and obstructed sphenoid sinus ostium (32.3\%). In addition, the uncorrected septal deviation, retained agger nasi cells or Haller cells and lateralized middle turbinate were also identified in the patients.

Conclusion From these data, we analyzed anatomical structures and CT findings related to the failure of primary ESS. We suggest that careful attention be given to these structures after primary ESS so as to reduce the failure rate and increase successful outcomes.

Korean J Otorhinolaryngol-Head Neck Surg 2013;56:764-8

Key Words Anatomical · Endoscopic sinus surgery $\cdot$ Recurrence $\cdot$ Sinusitis.

\section{서 론}

부비동 내시경 수술은 약물 치료에 반응하지 않는 만성 비 부비동염의 가장 기본적인 치료 방법으로, 1980년대 중반 부비 동 내시경 수술이 소개된 이래 비부비동 질환의 수술적 치료 는 비약적으로 발전하고 있다. 내시경을 통한 비강 및 부비동 의 해부학적 구조에 대한 연구가 활발해지고 있고 이러한 해부 학적 지식을 바탕으로 한 내시경 수술 술기에 대한 지식이 다 양해지면서 부비동 내시경 수술 후에 만성 비부비동염의 치료 성공률이 $76 \%$ 에서 $98 \%$ 까지 이른다. ${ }^{1)}$ 하지만 일차 부비동 내시
경 수술을 받은 후 3 년 내에 약 $12 \%$ 의 환자들이 재수술을 받 는다고 알려져 있고 부비동 내시경 수술 후에도 화농성 분비 물, 후각 저하, 호흡장애 등의 비부비동염 증상을 호소하는 환 자의 비율이 약 $20 \%$ 까지 보고되고 있다. ${ }^{2,3}$ 증상이 호전되었어 도 내시경 검사 소견으로는 점막 비후, 폴립 모양의 비강 점막 (polypoid nasal mucosa), 비용종, 끈적한 분비물(thick discharge) 등이 관찰되는 환자들의 비율까지 고려하면 더 많은 수의 환자에서 일차 내시경 수술로 완벽하게 치료되지 않았다 고 볼 수 있으며 추후에 재수술을 시행해야 하는 경우가 발생 하게 된다. 부비동 내시경 수술의 실패 원인에 대한 연구도 다 
양하게 이루어지고 있는데 수술 술기 자체의 문제를 제외하 면 수술 전에 시행된 이학적 검사 및 비부비동 전산화단층촬 영에서 관찰된 해부학적 구조에 대한 지식 부족이 가장 큰 원 인으로 알려지고 있다.) 따라서 재발되거나 완치되지 않은 비 부비동염은 약물 치료를 시도해 볼 수 있지만 치료에 반응하 지 않는 경우가 많아 결국은 재수술의 시행이 근본적 치료에 필수적이다. 비부비동 내시경을 통한 재수술을 시행할 경우 일 차 수술에 비해 해부학적 표지(landmark)의 변형으로 인해 안 와, 두개저 등의 정상 구조물에 손상을 줄 위험성이 높아진다. 또한 반흔 및 점막 부종에 따른 출혈이 일차 수술 때에 비하여 더 심하게 나타나고 골조직의 비후가 심해져 부비동을 완벽하 게 개방시키기가 어려워진다. 결과적으로 내시경 수술 후 합병 증이 생길 확률은 높아지고 치료 성공율은 일차 수술에 비해 떨어지게 된다. 따라서 일차 치료에 실패한 만성 비부비동염 환 자에서 관찰되는 비부비동의 해부학적 구조에 대한 분석과 특 히 전산화단층촬영을 통한 방사선학적 소견은 일차 수술의 실 패 원인 규명과 재수술의 성공률을 높이는 데 매우 중요하다. 하지만 재수술을 받는 환자의 비부비동 해부학적 구조 및 일 차 수술 후 남아있는 병변에 대한 분석 연구는 아직 충분하지 않아 많은 수술자들이 재수술시에는 육안으로 관찰되는 내 시경 소견에 의존하고 있는 실정이다.

본 연구는 만성 비부비동염의 재수술시 부비동 전산화단층 촬영(PNS-CT)에서 관찰되는 재발과 연관된 해부학적 소견 을 조사하고, 재발률을 낮추기 위해 부비동 내시경 수술시 주의 를 기울여 수술해야 할 해부학적 구조를 파악하기 위해 시행 되었다.

\section{대상 및 방법}

본 연구는 만성 비부비동염으로 부비동 내시경 수술을 받은 후 완치되지 않았거나 비부비동염의 재발이 의심되어 2011년 3월부터 2012년 12월까지 본원에 내원한 환자 중 천식 및 알레 르기 비염 등 알레르기 질환을 진단 받은 적 없고 만성 호흡기 질환에 대한 과거력이 없는 34명을 대상으로 이들의 의무 기록 과 PNS-CT 소견을 후향적으로 분석하였다. 만성 비부비동염 의 재발은 환자의 PNS-CT 소견과 비폐색감, 점액 농성 비루, 후비루, 안면통, 두통 등의 만성 비부비동염의 전형적 증상, 그 리고 점막의 발적이나 부종, 점액 화농성 분비물 등의 비내시 경 소견을 분석하여 진단하였다. 이전 부비동 내시경 수술 후 다시 부비동염의 재발을 진단 받기까지의 기간은 최대 12 년에 서 최소 1 년이었으며 평균 6.7 년이었다. 34 명 환자 모두에서 약 물 치료를 3주 이상 시행하였으나 증상의 개선이 없어 비부비 동 내시경 수술을 시행하였다. PNS-CT는 한 명의 방사선 전
문의에 의해 판독되었으며 이전 수술시 제대로 제거되지 않은 해부학적 구조를 조사하였다.

\section{결 과}

34 명의 환자 중 남자는 27 명, 여자는 7명이었으며 평균 연령 은 46.1세였고 이 중 29명의 환자는 한 차례 부비동 내시경 수 술을 받은 후 재발하였고, 5 명의 환자는 두 차례 이상의 부비 동 내시경 수술을 받은 후 재발하여 본원에 내원하였다. 7 명의 환자는 본원에서 수술을 시행 받았으며, 34 명 모두 양측 부비 동 내시경 수술을 받은 후에 비부비동염의 재발을 진단받았 다. 재발 횟수에 따른 환자의 성별, 과거 질병력, 약물 복용력, 나이 등에는 의미 있는 차이가 없었으며 흡연, 음주력에서도 통 계학적인 의의를 발견할 수 없었다.

만성 비부비동염의 재발과 관련 있을 것으로 생각되는 소 견은 크게 비중격 만곡, 중비갑개의 외측벽 유착, 남아 있는 구 상 돌기, 남아 있는 Haller 봉소, 남아 있는 비제 봉소, 남아 있 는 전사골동, 남아 있는 후사골동, 폐쇄된 접형동 자연공이었 다(Fig. 1).

PNS-CT 분석 결과 34명 중 이전 수술에서 교정되지 않은 남아 있는 구상 돌기는 16 명(47.0\%), 남아 있는 전사골동은 16 명(47.0\%)에서 관찰되었으며 만성 비부비동염의 재발로 진단 된 환자 중에서 가장 많이 관찰되었다. 남아 있는 후사골동의 경우 13명(38.2\%)이 관찰되었고 폐쇄된 접형동 자연공으로 인 해 접형동염이 관찰된 환자는 11 명(32.3\%), 재발된 부비동염의 방향으로 비중격 만곡을 보인 환자가 9명(26.4\%), 남아 있는 비 제 봉소는 8명(23.5\%), 남아 있는 Haller 봉소는 4명(11.7\%), 중 비갑개의 외측벽 유착은 2명(5.8\%)이 관찰되었다(Fig. 2). 단 순한 해부학적 소견에 대한 관측 외에 만성 비부비동염이 재 발한 양쪽을 모두 포함하여 다시 분석해 보면 34명의 환자의 총 68개의 쪽 중 이전 수술에서 교정되지 않아 남아 있는 전사 골동은 26쪽(38.2\%)에서 관찰되어 가장 많은 빈도를 보였으 며 남아 있는 구상 돌기는 25쪽(36.7\%), 남아 있는 후사골동은 20쪽(29.4\%)에서 관찰되었다. 남아 있는 후사골동이 관찰된 20쪽의 경우 모두에서 같은 방향의 남아 있는 전사골동을 동 반하였다. 폐쇄된 접형동 자연공으로 인해 접형동염이 관찰된 경우는 14쪽(20.5\%), 남아 있는 비제 봉소는 12쪽(17.6\%), 남아 있는 Haller 봉소는 4쪽(5.8\%), 중비갑개의 외측벽 유착은 2 쪽(2.9\%)에서 관찰되었다(Table 1). 또한 전두동, 전사골동, 후 사골동, 접형동, 상악동 중 부비동염이 재발한 빈도 순으로 정 리해 보면, 상악동염이 43쪽(63.2\%)으로 가장 재발이 많았고, 전사골동염이 28쪽(41.1\%), 후사골동염이 20쪽(29.4\%), 전두동 염이 15쪽(22.0\%), 접형동염이 14쪽(20.5\%)에서 관찰되었다. 

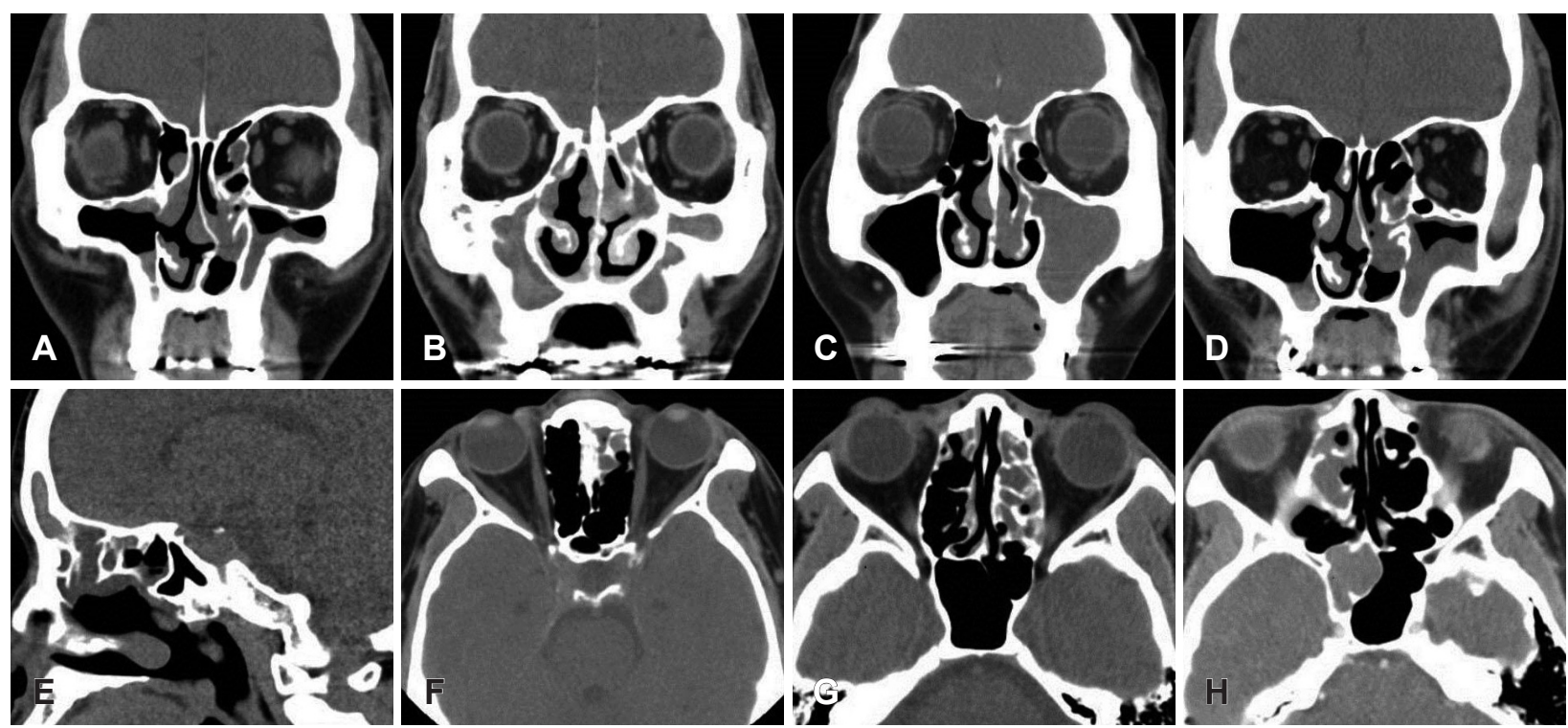

Fig. 1. Residual septal deviation (A). Lateralized right middle turbinate (B). Residual left uncinate process (C). Residual left Haller cell (D). Residual agger nasi cell (E). Residual left anterior ethmoidal cells (F). Residual left posterior ethmoidal cells (G). Residual right obstructed sphenoid sinus ostium $(\mathrm{H})$.

Fig. 2. Distribution and rate of anatomic CT findings in the subjects (total No.=34).

\section{고 찰}

기존의 여러 보고에 따르면 부비동 내시경 수술의 실패 및 만성 비부비동염의 재발은 수술과 연관된 요인과 환자가 가지 고 있는 기저질환이 크게 영향을 미친다고 알려져 왔다. 특히 기저질환과 만성 비부비동염의 예후에 대한 상관 관계에 대해 서는 다양한 연구가 이루어지고 있는데, 만성 비부비동염으 로 진단받은 환자가 기도 질환, 잘 조절되지 않는 비염, Samter's triad, 면역 결핍, 알레르기 진균성 부비동염 등의 질환이 동반되어 있거나 선천성 질환으로 인해 점액 섬모 운동 기능 이 감소된 경우는 적절한 수술적 치료에도 불구하고 치료 결
과 및 예후가 불량하다고 알려져 있다. 하지만 수술과 연관된 요인에 대한 분석은 명확하게 이루어져 있지 않으며 본 연구는 기저 질환은 배제하고 수술 자체와 연관된 실패한 요인을 분 석하고자 하였다.

기존에도 비부비동염의 재수술시 일차 수술 후 PNS-CT에 서 보이는 해부학적 구조물에 대한 논문은 많이 있었다. Ra$\operatorname{madan}^{2}$ 은 부비동 내시경 수술을 받은 398명 중 재수술을 받 게 된 52명에 대해 수술 후 전산화단층촬영 $(\mathrm{CT})$ 을 분석하여 중비갑개의 외측벽 유착, 남아 있는 사골동, 중비도 상악동 개 방술 부위 협착, 전두동 자연공 협착 등의 해부학적 구조가 만 성비부비동염의 재발과 밀접한 관련이 있다고 보고하였고, Par- 
Table 1. Anatomic findings of subjects who were diagnosed with recurred chronic rhinosinusitis

\begin{tabular}{lc}
\hline \multicolumn{1}{c}{ Anatomical abnormality } & Incidence $(\mathrm{n}=68)$ \\
\hline Residual uncinate process & 25 \\
Residual anterior ethmoidal cell & 26 \\
Residual posterior ethmoidal cell & 20 \\
Obstructed sphenoid sinus ostium & 14 \\
Septal deviation & 9 \\
Residual agger nasi cell & 12 \\
Residual Haller cell & 4 \\
Lateralized middle turbinate & 2 \\
\hline
\end{tabular}

sons 등근 부비동 내시경 수술 후 실패의 가장 큰 원인을 missed ostium sequence라 하였으며 다음 원인은 구상 돌기의 불 완전한 제거라고 설명하였다. Schaitken 등는 부비동 내시경 수술을 받은 91명 중 4년 내에 재수술을 받은 23명의 해부학 적 소견을 분석하였으며, 그 결과 재발한 비용종이 관찰된 경 우가 $40 \%$, 중비갑개와 비강 외측벽이 유착된 경우가 $22 \%$ 라 고 보고하였고, Lazar 등은 분비동 내시경 수술시 관찰되는 가장 많은 해부학적 소견으로 중비갑개와 비강 외측벽 사이의 섬유화와 유착이라 하였으며 그 다음은 재발된 비용종이라고 설명하였다. Musy와 Kountakis ${ }^{6}$ 는 비부비동염으로 재수술을 받게 된 70명에 대해 일차 수술 실패와 연관된 해부학적 요인 을 분석하면서 가장 많이 나타나는 빈도 순으로 중비갑개의 외측벽 유착, 불완전한 전사골동 제거술, 반흔성 전두와 남아 있는 비제 봉소 등의 구조가 재발과 관련있다고 보고하였다. Gore 등ㄱ은 부비동 내시경 재수술을 시행 받은 55명의 전산 화단층촬영을 분석한 결과 남아 있는 전사골동과 후사골동 이 $65 \%$ 로서 가장 높은 비율을 보였고, 남아 있는 비제봉소가 $52 \%$, 폐쇄된 접형동이 $51 \%$, 남아 있는 구상 돌기가 $46 \%$ 로 나 타났다고 보고하였다. 본 저자의 연구에서 만성 비부비동염의 재발로 진단된 환자들의 PNS-CT를 분석해 보면 위에서 보 고된 다른 논문들과는 달리 남아 있는 구상 돌기와 남아 있는 전사골동이 가장 많이 조사되었고, 상대적으로 중비갑개의 외 측벽 유착의 빈도는 2 명(5.8\%)으로 매우 적었으며, 여러 논문 들 간에 제대로 제거되지 않거나 교정되지 않은 해부학적 구조 의 빈도 및 분포에 차이가 있음을 알 수 있었다. 결국 국내에 서 시행된 만성 비부비동염의 수술적 치료시에는 의료진들이 상악동의 개구에 주로 집중하며 구상 돌기를 제대로 제거하고 전사골동을 여는 데는 다소 소홀하다고 생각이 되었고 이러 한 부분이 만성 비부비동염의 재발 및 완벽한 수술적 제거의 실패와 관련있다고 추정할 수 있었다.

예전에 구상 돌기가 오염된 외부 공기 및 알레르기 유발 항 원으로부터 부비동을 보호하는 역할을 한다며 보존하는 것이 좋다는 논문이 보고되었었고, 최근엔 minimally invasive si- nus technique가 소개되면서 보존적인 부비동 내시경 수술을 옹호하는 입장이 일고 있지만, ${ }^{899}$ 여전히 많은 술자들이 근치적 인 광범위 부비동 내시경 수술을 지지하고 있으며, 본 저자의 연구 및 위에서 언급한 여러 논문에서 보고된 것처럼 일차 수 술시 제거되지 않은 해부학적 구조물에 의해 비부비동염의 재 발이 많다고 판단되므로 침습적이더라도 위에서 언급한 방사 선학적 소견들을 교정해 주는 것이 필요하다고 생각한다.

본 연구에서는 다른 의료기관에서 일차 수술을 받고 재수 술을 위해 본원에 내원하여 PNS-CT를 시행한 환자도 포함 되어 있어 일차 수술시 병변이 완전히 제거되고 재발한 것인 지, 아니면 제거가 다 이루어지지 않은 것인지는 명확히 알 수 는 없어 연구된 해부학적 구조들이 반드시 재발과 관련이 있 다고는 단정할 수 없으나 적어도 이러한 해부학적 구조를 수술 전에 숙지하고 정확하게 제거해 주는 것이 수술의 성공 여부에 매우 중요하다고 할 수 있다.

비부비동염의 재수술시 부비동 주변 정상 구조물이 손상되 기 쉽고, 반흔 및 점막 비후에 의해 출혈이 일차 수술에 비해 많이 생기는 것으로 알려져 있으며 골성 비후에 의해 부비동 의 개방이 불충분하게 이루어질 가능성이 높아진다. 그리고 해 부학적 표지(landmark)가 일차 수술에 비해 모호하고 변형이 심하여 수술시 비부비동 주변의 중요 구조인 안와, 두개저, 눈 신경, 경동맥 등에 손상을 줄 위험성 및 합병증이 생길 가능성 이 크고 그 외 여러 요인에 의해 재수술 성공률이 $65 \%$ 에서 $78 \%$ 로 일차 수술에 비해 떨어지는 것으로 알려져 있다. $1,5,10,11)$ 따라 서 일차 부비동 내시경 수술시 정확한 해부학적 구조물을 숙지 하고 병변을 확실하게 교정해 주는 것이 중요하며 위에서 언급 한 8가지의 방사선학적 소견에 주의를 기울여 수술한다면 수 술 성공률을 높이고 재발을 줄임으로써 근치적인 만성 비부 비동염의 치료를 가능하게 할 수 있을 것으로 생각된다.

본 연구를 통해 저자들은 만성 비부비동염이 재발된 환자 의 PNS-CT 분석을 통해 일차 수술에서 잘 제거되지 않은 해 부학적 이상 소견을 추측할 수 있었으며 부비동 내시경 수술 시 이러한 부위에 좀더 주의를 기울여 수술하면 만성 비부비 동염의 재발을 줄이는 보다 바람직한 수술적 치료가 가능할 것으로 생각된다.

\section{REFERENCES}

1) Moses RL, Cornetta A, Atkins JP Jr, Roth M, Rosen MR, Keane WM. Revision endoscopic sinus surgery: the Thomas Jefferson University experience. Ear Nose Throat J 1998;77(3):190, 193-5, 199-202.

2) Ramadan $H H$. Surgical causes of failure in endoscopic sinus surgery. Laryngoscope 1999;109(1):27-9.

3) Parsons DS, Stivers FE, Talbot AR. The missed ostium sequence and the surgical approach to revision functional endoscopic sinus surgery. Otolaryngol Clin North Am 1996;29(1):169-83.

4) Schaitkin B, May M, Shapiro A, Fucci M, Mester SJ. Endoscopic 
sinus surgery: 4-year follow-up on the first 100 patients. Laryngoscope 1993;103(10):1117-20.

5) Lazar RH, Younis RT, Long TE, Gross CW. Revision functional endonasal sinus surgery. Ear Nose Throat J 1992;71(3):131-3.

6) Musy PY, Kountakis SE. Anatomic findings in patients undergoing revision endoscopic sinus surgery. Am J Otolaryngol 2004;25(6):41822.

7) Gore MR, Ebert CS Jr, Zanation AM, Senior BA. Beyond the "central sinus": radiographic findings in patients undergoing revision functional endoscopic sinus surgery. Int Forum Allergy Rhinol 2013;3(2):139-46.
8) Catalano PJ. Minimally invasive sinus technique: what is it? Should we consider it? Curr Opin Otolaryngol Head Neck Surg 2004;12(1): 34-7.

9) Catalano PJ, Strouch M. The minimally invasive sinus technique: theory and practice. Otolaryngol Clin North Am 2004;37(2):401-9, viii.

10) Jiang RS, Hsu CY. Revision functional endoscopic sinus surgery. Ann Otol Rhinol Laryngol 2002;111(2):155-9.

11) King JM, Caldarelli DD, Pigato JB. A review of revision functional endoscopic sinus surgery. Laryngoscope 1994;104(4):404-8. 